\title{
BIOLOGICAL REMEDIATION OF CYANIDE: A REVIEW
}

\author{
KARAMBA KABIRU IBRAHIM, MOHD ARIF SYED, MOHD YUNUS SHUKOR \\ and SITI AQLIMA AHMAD* \\ Faailty of BidechndoyyandBiomdeatlar Säenes Univesiti Putra Malaysia, \\ 43400 UPM Sedang SAangr, Malaysia
}

Received 8 April 2014/ Accepted 9 November 2015

\begin{abstract}
ABST RACT
Cyanide and its complexes are produced by industries all over the world as waste or effluents. Biodegradation is considered to be the cheapest and the most effective method to clean-up cyanide from the environment. Several studies on different types of microorganisms that can degrade cyanide in the environment have been carried out. Hydrolytic, oxidative, reductive and substitutive/ transfer reactions are some of the common pathways used by microorganisms in cyanide degradation. Biodegradation of cyanide can occur aerobically or anaerobically depending on the environmental conditions. Immobilized enzymes or microorganisms prove to be very effective method of degradation. Microorganisms such as Klebsidla oxytoa, Coryndbateriumnitrophilas, Breibacteiumnitrophilas Baillus spp., Psadommas spp. and Rhodbocas UK MP-5M have been reported to be very effective in biodegradation of cyanide.
\end{abstract}

Keywords: biodegradation, cyanide, environment, microorganisms

\section{INTRODUCTION}

Carbon and nitrogen elements form cyanide. They are ubiquitously found in the environment. Amygdalin, which is found in vegetables, fruits, seeds, cashew nuts, cherries, apricots and bean sprouts is a natural source of hydrogen cyanide (HCN) (Mark \& al. 1999). Chemical treatment is the most widely used method in the degradation of industrial effluents containing cyanide. But, this treatment is very expensive and sometimes inefficient in the process and thus requires an alternative means of treatment (Patil \& Paknikar 2000). Researches on microorganisms have been carried out to see if they can be an alternative means of cyanide degradation. Bioremoval has been reported to be less expensive than physical and chemical methods of cyanide degradation and faster than natural oxidation (O zel eal. 2010; D ash $\notin$ al. 2009). Destruction of cyanide in wastewaters and tailing solutions by capable microorganisms has been proved to be an alternative to the long-practiced chemical methods for the removal of cyanide. Biological methods of treating industrial effluents have been

\footnotetext{
* Corresponding author : aqlima@ upm.edu.my
}

reported to have high capital cost but low operating cost. Therefore, these methods are more profitable than the traditional process. Biological process that could satiate the need for extraction and environmental control is now practiced in some countries that understood the process (D ash «al. 2009).

\section{Cyanide Degrading Microorganisms}

Biological treatment process facilitates growth of microorganisms that are essential for treatment (Akcil 2003). It has been discovered that cyanide naturally occurs in the environment via the degradation of plant cyanogenic glycosides. A lot of microorganisms are able to detoxify simple forms of cyanide (Gadd 2001). Psadbmmas flurrescens NCIMB 11764 has been reported to be able to utilize potassium cyanide (KCN) in fed-batch culture (Kunz \& al. 1998). Psadommas fluorescencehas also been reported to degrade ferrocyanide (Arzu \& Zumriye 2000). The growth of Psaddommas fluarescens NCIMB 11764 on medium containing potassium cyanide (KCN) has also been reported (Kunz \&al. 1998). Cyanide degradation by Escheidhia coli, Alcaligenes 
Adintdbacter and Baillus species have also been reported in a number of studies.

It has been reported that strains of bacteria from genus Klebsidla are very effective in the bioremediation of cyanide and thiocyanate. $\mathrm{K}$. oxytoca isolated from an industrial waste containing high level of cyanide proliferates well with the cyanide as the only nitrogen source ( $\mathrm{K}$ ao eal. 2003). It has been reported that $K$ oxytocais effective in biodegradation even at concentrations higher than $1 \mathrm{mM}$ of cyanide (Chena $\notin a l .1999)$. The microorganism biodegrades cyanide to products that are nontoxic using cyanide as the only nitrogen source aerobically or anaerobically (Kao \& al. 2003; Stephen 2004). Seven bacterial strains isolated from gold mine environment in Korea have been found to be very effective in the biodegradation of thiocyanate with the initial concentration of $150 \mathrm{mg} / \mathrm{L}$ within sixteen days of incubation (Lee $\notin a l .2003)$. Four strains from the genus Baallus, one strain of Coryndbaderium nitrophilus and two from Brevibacteriumhave been found to effectively degrade cyanide.

Psardamonas psandbalcaligenes CECT5344 is an alkaliphilic strain of bacteria that is reported to be capable of biodegrading cyanide. The organism was isolated from sludge of Guadalquivir (Cordoba, Spain). It proliferates at an optimum $\mathrm{pH}$ of 9.5 and utilizes $2 \mathrm{mM}$ of cyanide as the only hydrogen source (Luque-Almagro \& al. 2005; Huertas \&al. 2010). The organism can also utilize complex of cyano-metal, cyanate and residue from jewellery industry as the sole nitrogen source (Luque-Almagro \&al. 2005). This strain has been described to possess a cyanide-insensitive respiration system, which includes cytochrome bot type alternate oxidase (AOX) that replaces the cytochromec oxidase (Q uesada eal. 2007).

\section{General Pathway Reaction for Biodegrada- tion of Free Cyanide}

There are four common pathways involved in the bioremoval of cyanide i.e. hydrolytic reaction, oxidative reaction, reductive reaction and substitution/transfer reaction. More than one pathway can be used for cyanide degradation by certain microorganisms (Raybuck 1992; EzziMufaddal \& Lynch 2005). The pathway to be used depends on various factors such as oxygen availability, $\mathrm{pH}$ level of the environment, concentrations of the cyanide and cyanide bioavailability and solubility in the soil water system (Aronstein \&al. 1994).

\section{Hydrolytic Reaction}

The following equations show the reactions that occur during hydrolytic pathway for cyanide degradation (D avid \&al. 2006):

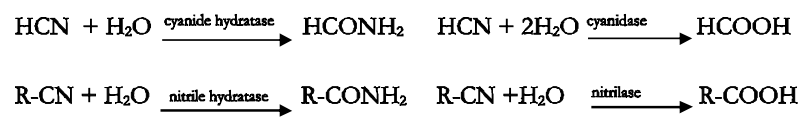

Hydrolytic reactions contain nitriles with $\mathrm{R}$ denotes either analiphatic or aromatic group. Hydrolytic reactions are catalyzed by cyanide hydratase, founding a formamide or cyanidase and yields formate and ammonia. Cyanide hydratase is principally a fungal enzyme and is extremely preserved between species (Barclay $\&$ al. 2002). Cyanide dihydratase (cyanidase) is produced chiefly by bacteria. Cyanide hydratase and cyanidase have, in recent times, been presented to have certain resemblances at both the amino acid and structural stages to nitrilase and nitrile hydratase enzymes (Reilly \& Turner 2003). Enzymes that utilize nitrile have been established in a wide variety of fungal, plant and bacterial species. Nitrilases and nitrile hydratases modify both aliphatic and aromatic nitriles to the equivalent acid or amide, respectively, but indicate less substrate specificity than cyanide hydratase and cyanide dihydratase. For instance, conversion of E. cdi with the cyanide hydratase gene from Fusanium lateitium permits the proliferation of nitriles as the only source of nitrogen. Sitedirected mutagenesis of this gene stops the activity of both cyanide hydratase and nitrilase, signifying that cyanide hydratase possesses nitrilase activity, as well (Nolan \& al. 2003). The variety of enzymes in this fantastic family and their diverse catalytic act and substrate specificities grant significant chance for biotechnological improvement, encompassing the bioremediation of industrial nitrile waste (Rezende đal. 2000; Dias \&al. 2001).

\section{Oxidative Reaction}

In the oxidative reaction, the cyanate formed by the enzyme cyanide monoxygenase is changed to ammonia and carbon dioxide by the same pathway as cyanate and thiocyanate (D avid $\notin$ al. 2006). 
$\mathrm{HCN}+\mathrm{O}_{2}+\mathrm{H}^{+}+\mathrm{NAD}(\mathrm{P}) \mathrm{H} \underset{\text { cyanide monoxygenase }}{\longrightarrow} \mathrm{HOCN}+\mathrm{NAD}(\mathrm{P})^{+}+\mathrm{H}_{2} \mathrm{O}$ $\mathrm{HCN}+\mathrm{O}_{2}+2 \mathrm{H}^{+}+\mathrm{NAD}(\mathrm{P}) \mathrm{H} \stackrel{\text { cyanide dioxygenase }}{\longrightarrow} \mathrm{CO}_{2}+\mathrm{NH}_{3}+\mathrm{NAD}(\mathrm{P})^{+}$

Cyanide is converted to cyanate by cyanide monoxygenase with cyanate standing as the catalyst for conversion of cyanate to ammonia and carbon dioxide dependent on bicarbonate. Cyanases have been identified in several bacteria, fungi, plants and animals (Guilloton $\notin$ al. 2002). The assumed task of cyanase has, for a long time, been as a defense against poisoning by cyanate (Raybuck 1992). As cyanate is not a familiar metabolite, new essential roles in favor of cyanases in nitrogen and bicarbonate/ carbon dioxide metabolism have been suggested. More proposed roles for plant cyanases comprise ammonia absorption as a result of cyanate bioremediation and a task in the concentration and deliverance of carbon dioxide for photosynthesis (Guilloton $\notin a l$. 2002).

Another oxidative pathway makes use of cyanide dioxygenase to produce ammonia and carbon dioxide directly (Stephen 2004). Moreover, in E. cdi strain BCN6 and P. flucresens NCIMB 11764 , the production of cyanohydrin complexes is reportedly essential for oxygenase-mediated cyanide biodegradation (Kunz \&al. 1998; Figueira eal. 1996).

\section{Reductive Reaction}

The reductive pathway results from the act of nitrogenase enzyme and the products ensuing from transfer of pair of electrons (Stephen 2004; D avid eal. 2006).

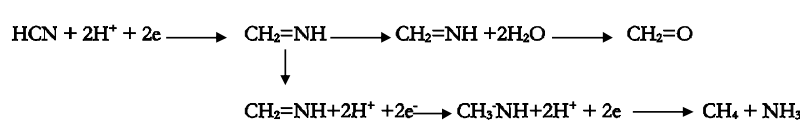

Studies have been carried out in two bioreactors in cassava wastewaters and synthetic wastewater. This indicates a clear reductive process on biodegradation (Paixao \&al. 2000; Annachhatre \& Amornkaew 2000). The studies indicate that the anaerobic bioreactors prop up the proliferation of methanogenes which can result in the production of biogas. The increase in the cyanide concentration inhibits methanogenesis from anaerobic biogranules. This effect could be a result of high cyanide concentration in the feed stock (Annachhatre \& Amornkaew 2000).

\section{Substitution/ TransferReaction}

This is referred to as assimilatory pathway. Several genera of bacteria are said to assimilate cyanide. This reaction is more extensively researched in Chrombacterium vidacam Other bacteria that utilize this reaction include Escheidhiacdi, Baallusmegaterium Citrdbader fremdi and Enterdbader aerogenes (D avid \& al. 2006). The substitution/ transfer reaction uses cyanoalanine synthase enzyme as the catalyst using 0acetylserine (OAS) as substrate.

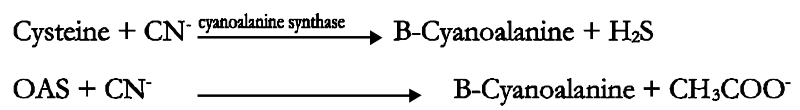

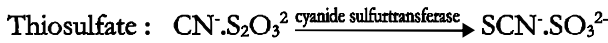

The cyanate produced by cyanide monoxygenase is changed to $\mathrm{NH}_{4}^{+}$and $\mathrm{CO}_{2}$ by very similar pathway as the cyanate from thiocyanate(Stephen 2004).

\section{Thiocyanate Biodegradation}

Reactions of cyanide with pyretic materials in effluents lead to the production of thiocyanate. The enzyme that is responsible for the production of thiocyanate in vivois sulfurtransferase via the action of thiosulfate-cyanide. Its biodegradation can be achieved by at least two pathways namely, cyanate and carbonyl pathways (D avid \&al. 2006; Kwon \&al. 2002; Plessis \&al. 2001; Sorokin \&al. 2001; Yamasaki \&al. 2002).

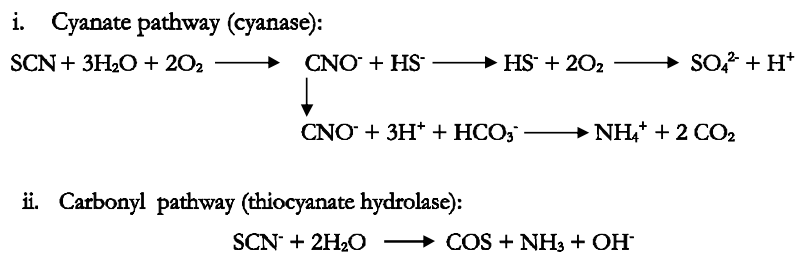

Three species of thiocyanate-degrading bacteria obtained from very high alkaline soda lagoon soils and sediments produce high amounts of cyanate when grown at $\mathrm{pH} 10$ with thiocyanate as the only source of nitrogen. The activity of cyanase that converts cyanate to carbon dioxide and ammonia is also high (Sorokin \& al. 2001). The fungus Acremoniumstricumproduces sulphate and ammonia from thiocyanate devoid of the production of cyanate (Kwon \& al. 2002). In the 
carbonyl pathway, the thiocyanate is transformed to ammonia and carbonyl sulphide. The confirmation for this pathway is as a result of the identification of thiocyanate hydrolase that is responsible for the transformation in the chemolithotroph Thidbaillus thiqpanus and the genes encoding this enzyme have been acknowledged in other thiocyanate-degrading bacterial cultures (Yamasaki \&al. 2002).

\section{Aerobic Biodegradation of Cyanide}

The process of biodegradation that requires the use of oxygen is termed as aerobic system of biodegradation. Under aerobic conditions, cyanide is broken down by cyanide-oxidizing bacteria into harmless compound. The process degrades hydrogen cyanide and produces hydrogen cyanate, which then undergoes hydrolysis to form ammonia and carbon dioxide as shown in the equation below:

$$
\begin{aligned}
& 2 \mathrm{HCN}+\mathrm{O}_{2}+\text { Enzyme } \longrightarrow 2 \mathrm{HCNO} \\
& \mathrm{HCNO}+\mathrm{H}_{2} \mathrm{O} \longrightarrow \mathrm{NH}_{2}+\mathrm{CO}_{2}
\end{aligned}
$$

Reports have indicated that aerobic process of biodegradation is many times faster and better than anaerobic degradation (Stephen 2004). Algae such as Arthrospira maxima, Scenedesmis dbiquus, and Chlorella spp. have also been reported in the detoxification of cyanide (D wivedi $\notin$ al. 2011; Gurbuz \&al. 2009).

\section{Anaerobic Biodegradation of Cyanide}

Anaerobic system of biodegradation is the process that occurs in the absence of oxygen (D wivedi $\notin$ al. 2011). Fedorak and Hurudey in 1989 was the first to report biotreatment of cyanide anaerobically using semi continuous batch cultures and Hydraulic Retention Time (HRT) of 25 days for one liquid volume replacement (Fallon eal. 1991). A naerobic biodegradation can only occur in the presence of $\mathrm{HS}_{2}$ or $\mathrm{H}_{2} \mathrm{~S}$ and is restricted to reduce portion of the heap environment. The sulphur species that is present depends on the $\mathrm{pH}$. At $\mathrm{pH} \geq 7, \mathrm{HS}_{2}$ is the species that is dominant and at $\mathrm{pH} \leq 7$ although $\mathrm{H}_{2} \mathrm{~S}$ is the more dominant species of sulphur in other $\mathrm{pHs}$ (D wivedi eal. 2011).

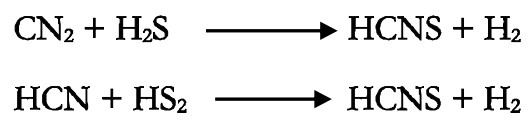

The HCNS will undergo hydrolyses to produce $\mathrm{NH}_{2}, \mathrm{H}_{2}$ Sand $\mathrm{Co}_{2}$.

Anaerobic cyanide biodegradation has been proven to be a concomitant method of biogas generation that is of economic benefit (Stephen 2004). Under anaerobic condition, biodegradation results in the formation of nitrogen as the end product. Furthermore, anaerobic treatment is not fast and it is more vulnerable to toxic upsets ensuing from exposure to other elements present in the solution undergoing the treatment. In addition, cyanide toxicity threshold for anaerobic bacteria is only $2 \mathrm{mg} / \mathrm{L}$, while aerobic bacteria have $200 \mathrm{mg} / \mathrm{L}$ threshold. Therefore, anaerobic bioremoval is considered to be less effective method of bioremoval mechanism (Stephen 2004).

\section{Effect of Immobilization on Cyanide Biodegradation}

Immobilization has been reported to be a very effective and efficient tool of biodegradation. This tool offers many economic and technical advantages over the free cell type as it offers the possibility of maintaining the cells in a stable and viable condition with high specific surface area for microbial proliferation (Dursun \& Aksu 2002). Immobilized cells are less vulnerable to compounds that are toxic and exhibit high tolerance towards distress in the reaction environment (Chen $\&$ al. 2008). Moreover, immobilized cells are more advantageous when compared with the use of free cells because of the ability to support higher concentration of cell density and eliminate the difficult, timeconsuming and expensive process of cell recovery and recycling (Zhou \& al. 2007). Bioremediation by Candida gilliemmodii CCT 7207 was very effective on immobilized cells (Dias \& al. 2001). This is a remark that reiterates previous researches indicating that immobilized microorganisms or enzymes make available an active stage for bioremediation (Stephen 2004). Effective biodegradation of cyanide compounds by P. fluorescens immobilized on zeolite has been reported (Suh \& al. 1994). M. G raca Campos in 2005 reported effective, feasible and efficient detoxification of cyanide by immobilized Fusarium oxysporum CCMI 876 and Methyldbadteium sp. RXM CCMI 908 using a packed bed reactor for integrated biodegradation 
of cyanide (Campos \& al. 2006). Maegala $\&$ al. (2012) reported effective biodegradation of cyanide by immobilized cells of Rhobbowas UKMP.

\section{Oxygenation in Immobilized Cell Culture}

Oxygenation is a major challenge in immobilization. Researchers have reported critical challenges in supplying sufficient and adequate concentration of oxygen in order to keep high amount of viable and productive cells throughout a culture period (Meuwly \& al. 2005). In packed bed reactors it was observed that if there is low supply of oxygen, there will be decrease in viability of culture, metabolic activity and productivity until optimal supply of oxygen is achieved. This is because oxygen has avery poor solubility in cell culture medium (Fassnacht \& Portner 1999).

\section{Factors Affecting Cyanide Biodegradation in E nvironment}

The presence of microorganisms that have the physical and metabolic abilities to degrade the contaminants in the polluted environment ensures the success of biodegradation. Cyanide compounds are found broadly in natural surroundings and the metabolic degradation of these compounds by microorganisms is thus possible. However, the following factors affect the process ( $\mathrm{K}$ ao \& al. 2006; Baxter \& Cummings 2006; D ash \&al. 2009):

- Cyanide concentration in the environment can have significant effect in the treatment. For instance, high concentration of acetonitrile has been proved toxic to Kldbsidlaoxytocaby causing damage to nitrile hydratase, which is the nitriledegrading enzyme and by preventing bioremoval of the compound by the microorganism.

- Biodegradation of cyanide compounds can be affected by the availability of nutrients. Carbon has been recognized as the restrictive factor in the biodegradation of cyanide compounds, which may make the biodegradation of industrially polluted soils not feasible.

- Aeration is very important in the biodegradation of cyanide as oxygen is required during the degradation pathways.

- Cyanide toxicity can be paramount to anaerobic bacteria principally methanogens.
O ther contaminants present at the polluted areas may also affect bioremoval.

- Existence of high concentration of other pollutants can have negative effect on degradation of cyanide by swaying the native population and possibly hindering the proliferation of specific organism.

\section{Biodegradation of Free/ complex Cyanide and Thiocyanate}

In the biotreatment of cyanide, bacteria have the capacity to change free and metal cyanides to bicarbonate and ammonia, whereas the free metals are adsorbed within the biofilm or unconfined as precipitates in solution. Alkali metal cyanides such as potassium cyanide (KCN) and sodium cyanide $\left(\mathrm{NaCN}_{2}\right)$ are easily being degraded by different forms of bacteria across the globe. In 1969 in USA, free cells of Baallus megateium was reported to degrade potassium cyanide (Castric \& Strobel 1969). In the same year in Canada, free cells Badlluspumiluswas reported to degrade $2.5 \mathrm{mg} / \mathrm{L}$ of potassium cyanide at the $\mathrm{pH}$ of 8.5-9.0 and temperature of $40{ }^{\circ} \mathrm{C}$ (Skowronski \& Strobel 1969). In 1972, free cells of Stemphyiumldi, which is a pathogenic fungus of the cyanogenic plant 'Bird's Foot-Trefoil' (Lcus comiaulatus L.) (Fry \& Mills 1972) was reported to degrade $0.97 \mathrm{M}$ of potassium cyanide at $\mathrm{pH}$ of 6.5-7.5 and temperature of $25^{\circ} \mathrm{C}$ with the removal efficiency of $77 \mathrm{nM}$ (Fry \& Mills 1972). Several reports have been reviewed across the world up to the year 2012. In Malaysia Rhodococaus UKMP-5M in both free and immobilized forms was reported to degrade potassium cyanide at $30{ }^{\circ} \mathrm{C}$ temperature condition with the removal efficiency of 64 and 96\%, respectively (Maegala edal. 2011; Maegala $\notin$ al. 2012). This removal capacity is not only limited to bacteria but other fungal organisms such as Fusaniumsdani, which in 1997 its free cells were reported to degrade potassium cyanide concentration of $0.5-0.8 \mathrm{mM}$ at the $\mathrm{pH}$ of 9.2-10.7 and temperature condition of $30^{\circ} \mathrm{C}$ in France (D umestre etal. 1997). In 1975, free cells of B. stearthemphilusNCA 1503 was reported to degrade $\mathrm{NaCN}_{2}$ and $\mathrm{NaHSO}_{3}$ with initial concentration of $5 \mathrm{mM}$ and $50 \mathrm{mM}$ at apH of 7.8 and temperature of $27 \pm 2{ }^{\circ} \mathrm{C}$ with the removal efficiency of 5-8 $\mathrm{g} / \mathrm{L} /$ hour (A tkinson 1975). The simplicity within which the complexes of metal 
cyanide are being degraded commonly follows the sort of general stability, with free cyanides being the readily degradable while cyanide of iron being the least degradable. Zinc (Zn), nickel (Ni) and copper $(\mathrm{Cu})$ are moderate in terms of degradability of their metal cyanides (Young \& Jordan 1995; Botz 2001). A study conducted in Korea in 1994 reveals that P. fluorescens immobilized on zeolite was able to degrade Tetracyano Nickelate II at $30{ }^{\circ} \mathrm{C}$ (Suh \& al. 1994). Studies in Turkey in 1999 showed that immobilized P. fluarescens was able to degrade ferrous (II) cyanide complex (Dursun \&al. 1999) while free cells of $P$. flucrescenswas able to degrade $100 \mathrm{mg} / \mathrm{L}$ ferrous (II) cyanide complex at pH 5 and temperature of $25{ }^{\circ} \mathrm{C}$ at degradation rate of $30 \mathrm{mg} / \mathrm{g} /$ hour (D ursun \&al. 1999). Free cells of Citrdbacter spp. and Pseadommas spp. were reported in India to degrade $52 \mathrm{mg} / \mathrm{L}$ metal cyanide complexes such as copper cyanide and zinc cyanide with the removal efficiency of $>$ 99.9\% (Patil \& Panikar 2000). In the United Kingdom in 2005, free cells of Tridodama sp. and Fusaniumsp. were reported to degrade 2,000 $\mathrm{mg} / \mathrm{L}$ metallo cyanide at $\mathrm{pH} 6.5$ and temperature of $25{ }^{\circ} \mathrm{C}$, with the removal efficiency of 2,000 ppm (Ezzi-Mufaddal \& Lynch 2002). D egradation of complex cyanide is not limited to only bacteria because in the United Kingdom in 1998, mix cultures of Fusaniumsdani, T. pdysponum
F. oxysponum Satalidium thempohilum and Peniaillium micyndki were reported to degrade $\mathrm{K}_{2} \mathrm{Ni}(\mathrm{CN})_{4}$ and $\mathrm{K}_{4} \mathrm{Fe}(\mathrm{CN})_{6}$ at a concentration of $0.75 \mathrm{mM}$ and $0.25-1 \mathrm{mM}$ concentrations and pH 4.5-7.0 and temperature conditions of $25^{\circ} \mathrm{C}$ with the removal efficiency of $50-56 \%$, respectively (Barclay \&al. 1998). In 2001 in South Africa, some free cells of microorganisms were reported to degrade thiocyanate at the concentration of $500 \mathrm{mg} / \mathrm{L}$ with the removal efficiency of $0.5 \mathrm{mg} / \mathrm{L} / \mathrm{h}$ (Sorokin $\mathrm{eal}$. 2001). In the same year in Russia, free cells of Alkaliphilic bacteria were reported to degrade $40 \mathrm{mM}$ initial concentration of thiocyanate at a pH 10 and temperature of $28^{\circ} \mathrm{C}$ with removal efficiency 4 mM (Plessis \& al. 2001). In 2002 in Korea, Acemmiumstridumwas reported to degrade 7.4 $\mathrm{g} / \mathrm{L}$ concentration of thiocyanate at a $\mathrm{pH} 6$ with $100 \%$ removal efficiency in 85 hours (Kwon \&al. 2002). In 2002 in Tokyo, Japan, free cells of Thidbaallus thippans THI115 was reported to degrade thiocyanate with initial concentration of $0.1 \mathrm{~g} / \mathrm{L}$ at a temperature of $30^{\circ} \mathrm{C}$ (Yamasaki \&al. 2002). There is no doubt from this review that Psaddommas sp. has an upper hand in the degradation of both free and complex cyanides in quite a number of countries across the globe. Table 1 summarizes the degradation potentials of some microorganisms on free and complex cyanides and thiocyanate. 
Biological remediation of cyanide: A review - Ibrahim \&al.

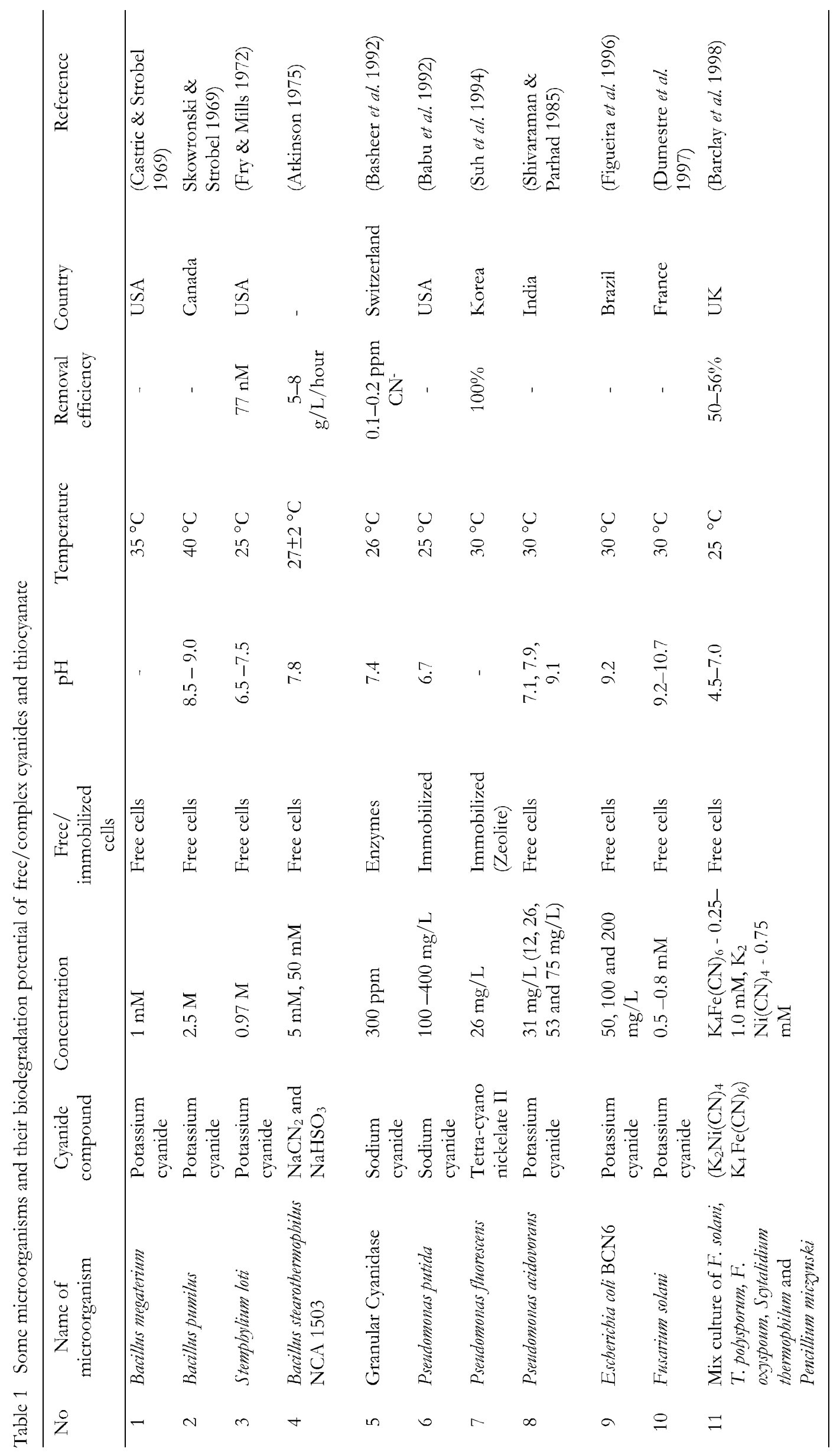


BIOTROPIA Vol. 22 No. 2, 2015

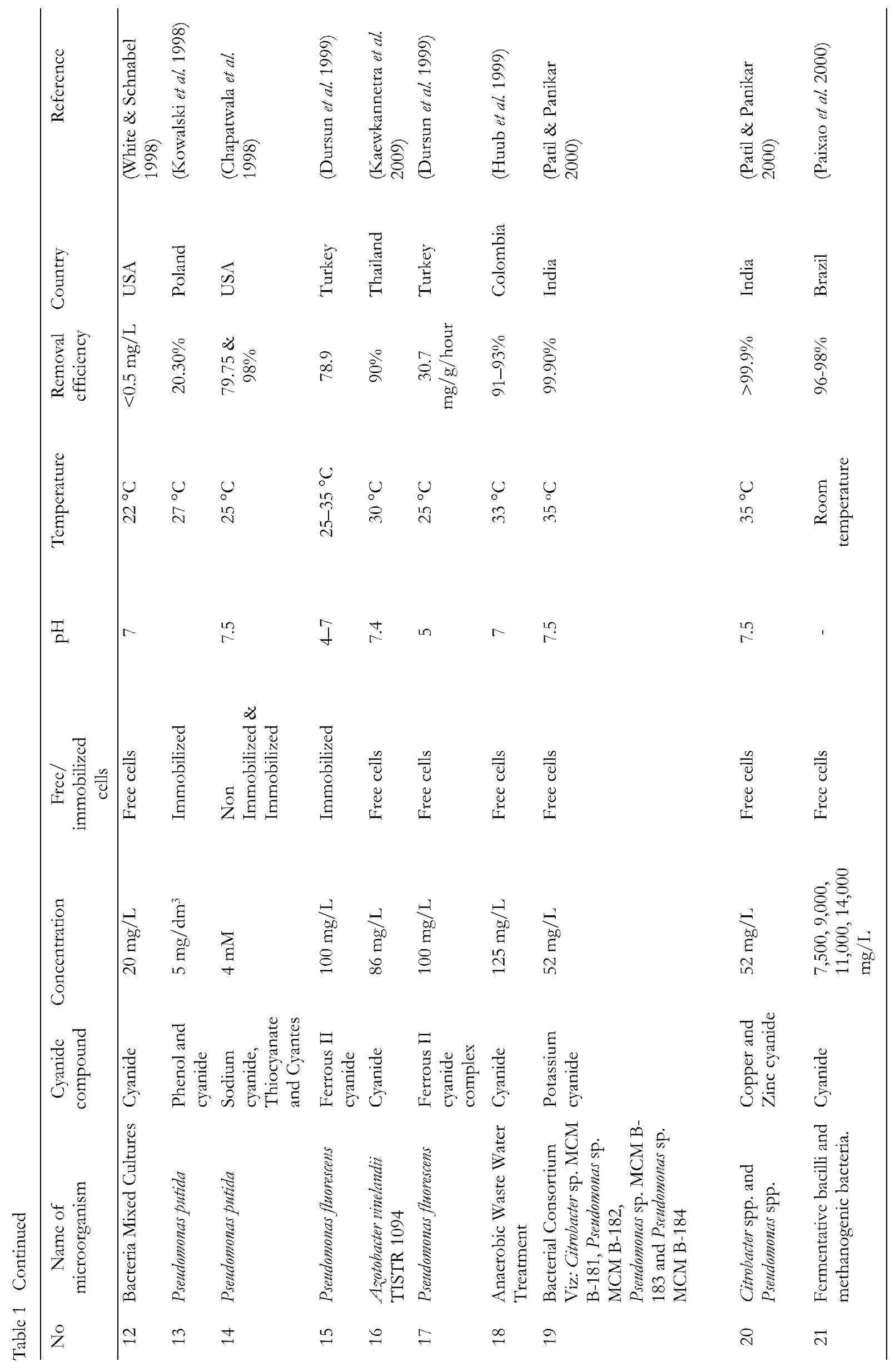


Biological remediation of cyanide: A review - Ibrahim \&al.

\begin{tabular}{|c|c|c|c|c|c|c|c|c|c|c|c|c|}
\hline 苞 & 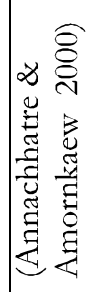 & 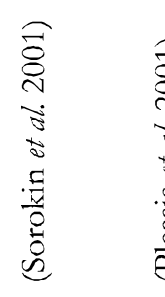 & 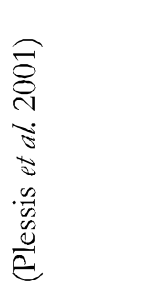 & 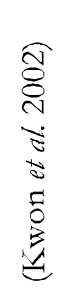 & 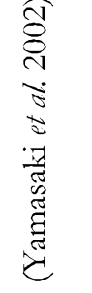 & 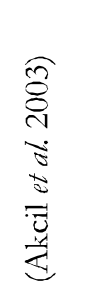 & 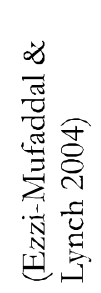 & 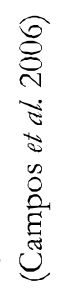 & 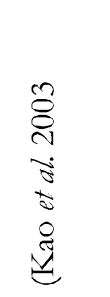 & 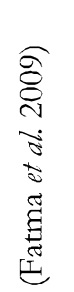 & 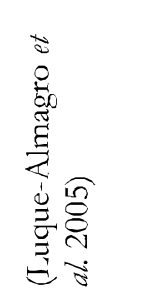 & 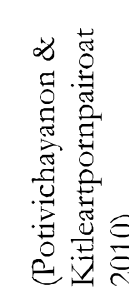 \\
\hline 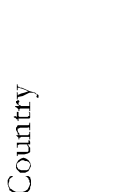 & 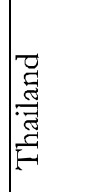 & 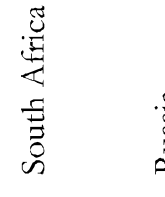 & 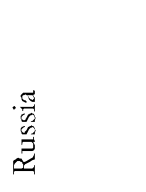 & 莺 & $\frac{0}{\stackrel{0}{0}}$ & 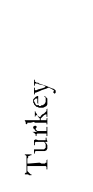 & $\breve{b}$ & 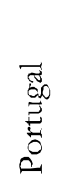 & , & 窎 & 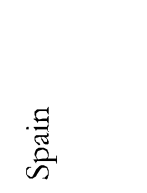 & 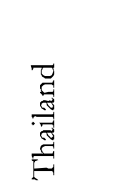 \\
\hline 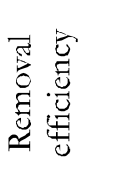 & 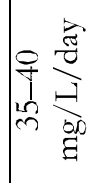 & 날 & 音 & $\begin{array}{l}\stackrel{\leftrightarrow}{\infty} \\
\stackrel{+}{+}\end{array}$ & & & 总总 & $\stackrel{\circ}{\circ}$ & 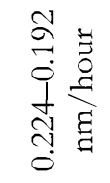 & $\begin{array}{l}\text { oे } \\
\text { लें } \\
\text { న్ }\end{array}$ & 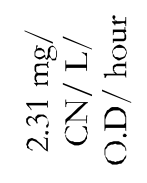 & 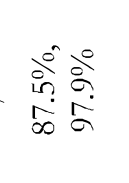 \\
\hline 苋 & $\begin{array}{l}0 \\
0 \\
0 \\
0\end{array}$ & $\begin{array}{l}u \\
\text { o } \\
\sim \\
\sim\end{array}$ & 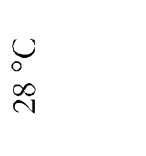 & $\begin{array}{l}u \\
\stackrel{u}{i} \\
i\end{array}$ & $\begin{array}{l}0 \\
0 \\
\infty\end{array}$ & $\begin{array}{l}0 \\
0 \\
0\end{array}$ & $\begin{array}{l}u \\
\text { in } \\
\text { in }\end{array}$ & $\begin{array}{l}0 \\
0 \\
0 \\
i 1 \\
u n \\
\end{array}$ & $\begin{array}{l}\dot{0} \\
\dot{m}\end{array}$ & $\begin{array}{l}0 \\
0 \\
0 \\
\wedge\end{array}$ & $\begin{array}{l}0 \\
\dot{m} \\
0\end{array}$ & $\begin{array}{l}u \\
\dot{m}\end{array}$ \\
\hline I & & 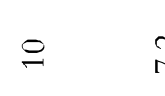 & $\stackrel{?}{?}$ & 0 & $r$ & $\stackrel{+}{\stackrel{\vec{J}}{d}}$ & 煦 & $\infty$ & $r$ & $\stackrel{?}{\stackrel{3}{g}}$ & $\stackrel{n}{\alpha}$ & $\stackrel{?}{?}$ \\
\hline 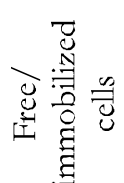 & & 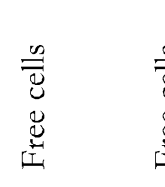 & 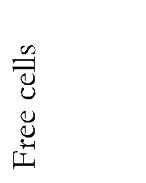 & 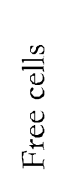 & 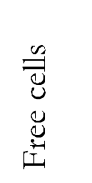 & 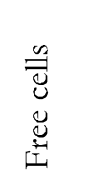 & 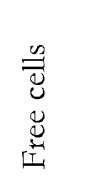 & 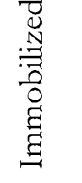 & 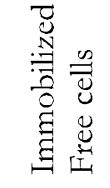 & 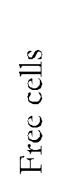 & 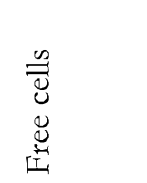 & 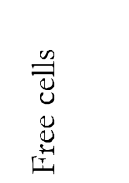 \\
\hline 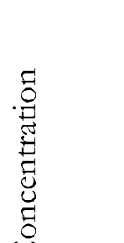 & 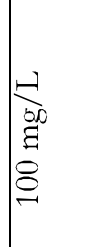 & 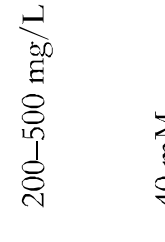 & $\begin{array}{l}\text { 芛 } \\
\text { 虽 }\end{array}$ & 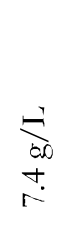 & $\begin{array}{l}\vec{b} \\
\overrightarrow{0} \\
\overrightarrow{0}\end{array}$ & 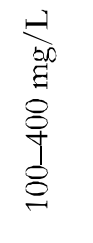 & 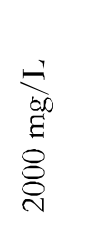 & $\begin{array}{l}\text { I } \\
\text { I } \\
\text { I }\end{array}$ & $\underset{\text { In }}{\sum_{n}}$ & 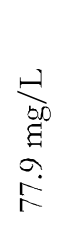 & 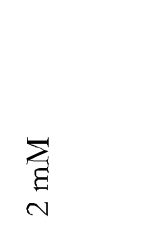 & 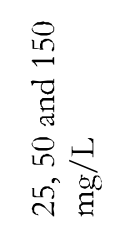 \\
\hline 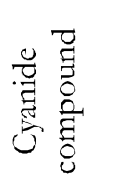 & 藏 & 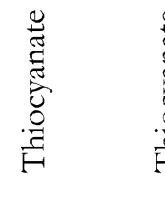 & 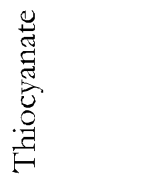 & 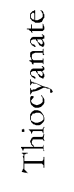 & 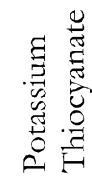 & 鄫司 & . & 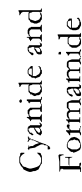 & 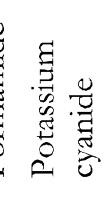 & 是 & 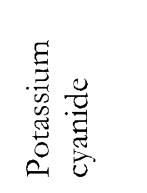 & 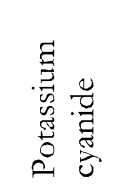 \\
\hline 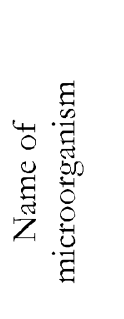 & 总 & 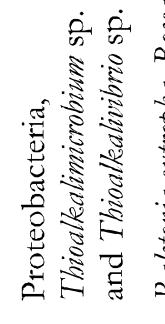 & 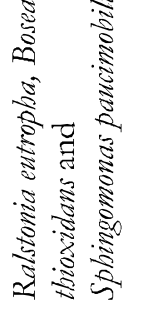 & 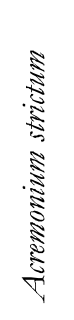 & 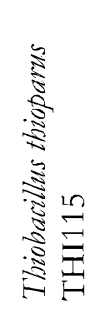 & 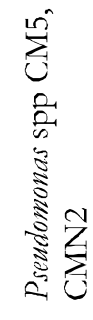 & 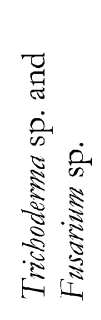 & 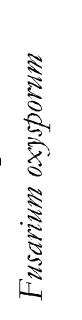 & 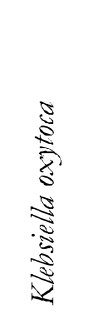 & 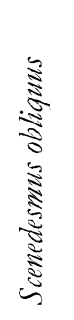 & 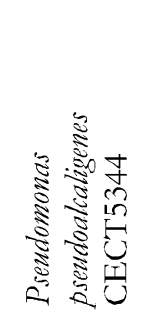 & 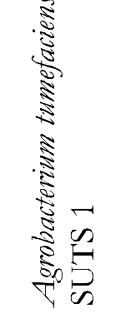 \\
\hline$\stackrel{8}{z}$ & กิ & $\ddot{i}$ & $\stackrel{+}{\mathrm{d}}$ & $\stackrel{\sim}{\sim}$ & $\stackrel{\sim}{\sim}$ & $\hat{\sim}$ & $\stackrel{\infty}{\sim}$ & ते & $\ddot{n}$ & $\vec{m}$ & $\approx$ & $\ddot{m}$ \\
\hline
\end{tabular}


BIOTROPIA Vol. 22 No. 2, 2015

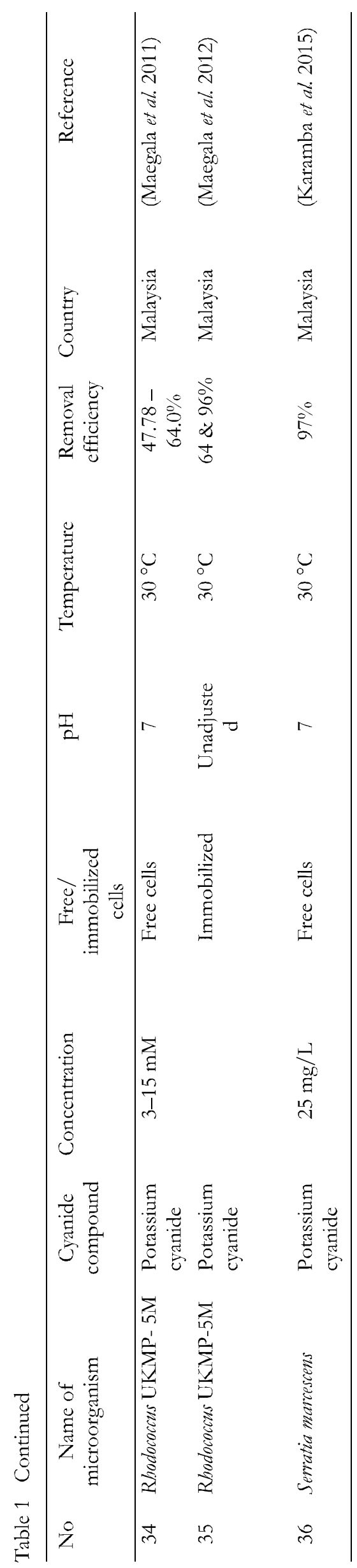




\section{CONCLUSIONS}

Certain economic and physical factors chiefly limit the use of biotechnologies in the degradation of cyanide. Biodegradation is potentially the cheapest means to get rid of cyanide but factors such as $\mathrm{pH}$, temperature and nutrients concentration of the cyanide affect the process. Bioremoval can be achieved under aerobic and anaerobic conditions. Free and immobilized cells have proven to be very effective and efficient methods of biodegradation. The microbes potentially have certain enzymes that can change cyanide into naturally occurring compounds. Four types of pathways are used by the microorganisms to biodegrade and one or combination of two pathways can be employed in the process by microorganisms (Raybuck 1992; Ezzi-Mufaddal \& Lynch 2002). Psaddomonas spp. shows great capability for cyanide removal. In 2011 and 2012, Rhoobocous UKMP-5M obtained from Culture Collection Unit, Institute of Bio-IT Selangor was reported to be used to degrade potassium cyanide in free and immobilized forms and it has been proven to be efficient in the degradation (Maegala \& al. 2011; Maegala \& al. 2012). Table 1 indicates that from 1969 to date, researches have been carried out on the bioremoval of cyanide. However, despite all the investigations that have proved microorganisms can degrade cyanide in the laboratory; it has not been accomplished in a largescale(Fatma \&al. 2009).

\section{REFERENCES}

Akcil A. 2003. Destruction of cyanide in gold mill effluents: biological versus chemical treatments. Biotechnol Adv 21:501-11.

Akcil A, Karahan AG, Ciftci H, Sagdic O. 2003. Biological treatment of cyanide by natural isolated bacteria (Psendomonassp.). Miner Eng 16:643-9.

Annachhatre AP, Amornkaew A. 2000. Toxicity and degradation of cyanide in batch methanogenesis. Environ Techno 21:135- 45.

Aronstein BN, Maka A, Srivastava VJ. 1994. Chemical and biological removal of cyanides from aqueous and soil-containing systems. Appl Microbiol Biot 41: 700- 7 .

Arzu YD, Zumriye A. 2000. Biodegradation kinetics of ferrous (II) cyanide complex ions by immobilised Psardomonasfluorescensin packed bed column reactor. Proc Biochem 35: 615- 22.
Atkinson A. 1975. Bacterial cyanide detoxification. Biotechno Bioeng 17: 457-60.

Babu GRV, Wolfram JH, Chapatwala KD. 1992. Conversion of sodium cyanideto $\quad \mathrm{c} \mathrm{a} \mathrm{r} \mathrm{b} 0 \mathrm{n}$ dioxide and ammonia by immobilised cells of Psaddmonaspatica J Ind Microbiol 9: 235-38.

Barclay M, D ay JC, Thompson IP, Knowles CJ, Bailey MJ. 2002. Substrate-regulated cyanide hydratase (chy) gene expression in Fusaniumsdani: the potential of a transcription-based assay for monitoring the biotransformation of cyanide complexes. Environ Microbiol4:183-9.

Barclay M, Hart A, Knowles CJ, Meeussen JCL, Tett VA. 1998. Biodegradation of metal cyanides by mixed and pure cultures of fungi. EnzymeMicrob Tech 22: 223-31.

Basheer S, Kut O M, Prenosil JE, BoumeJR. 1992. Kinetics of enzymatic degradation of cyanide. Biotechnol Bioeng 39:629-34.

Baxter J, Cummings SP. 2006. The current and future application of microorganism in the bioremediation of cyanide contamination. Anthony Van Leeuwenhoek 90:1-17.

Botz MM. 2001. Overview of cyanide treatment methods. In: Mudder $\mathrm{T}$, editor. Mining Enviranmental Manacement. London (UK): Mining Journal Ltd. p 28-30.

Campos MG, Pereira P, Roseiro JC. 2006. Packed-bed reactorfortheintegrated biodegradation of cyanide and formamide by immobilised Fusarium oxysponumCCMI 876 and Methyldbaderiumsp. RXM CCMI 908. Enzyme Microb Tech 38: 848-54.

Castric PA, Strobel GA. 1969. Cyanide metabolism by BaillusmegateriumJ Biol Chem 244: 4089-94.

Chapatwala KD, Babu GRV, Vijaya OK, Kumar KP, Wolfram JH. 1998. Biodegradation of cyanides, cyanates and thiocyanates to ammonia and carbon dioxide by immobilised cells of Psadommasputica J Ind Microbiol 20: 28-33.

Chen CY, K ao CM, Chen SC. 2008. Application of Klebsdla oxytora immobilised cells on the treatment of cyanide wastewater. Water Sci Tech 71: 133-9.

Chena SC, Liu JK. 1999. The response to cyanide of cyanide-resistant Klebsidla oxytoca bacterial strain. FEMS Microbiol Ecol 175: 37-43.

Dash RR, Gaur A, Balomajumder C. 2009. Cyanide in industrial waste waters and its removal: a review on bio-treatment.J Hazard Mater 163: 1- 11.

D avid AD, Rajat SG, G eorge M, Wong C. 2006. Cyanide in water and soil: Chemistry, Risk and Management. CRC Press. p. 121-607.

Dias JCT, Rezende RP, Linardi VR. 2001. Bioconversion of nitriles by Candida gilliemmodi CCT 7207 cells immobilised in barium alginate. Appl Microbiol Biotechnol 56: 757-61. 
D umestre A, Chone T, Portal J, Berthelin J. 1997. Cyanide degradation under alkaline conditions by a strain of Fusarium solani isolated from contaminated soils. ApplE nviron Microbiol 63: 2729-34.

D ursun AY, Alik AC, Aksu Z. 1999. D egradation of ferrous (II) cyanide complex ion by Psandommasflunresens Proc Biochem 34: 901-8.

D ursun AY, Aksu Z. 2002. Effect of internal diffusivity of ferrous (II) cyanide complex ions in cal-alginate immobilised Psaddononesflunescensgel beads on the biodegradation rate. Proc Biochem 37: 747- 52.

D wivedi N, Majunder CB, Mondal P, Dwivedi S. 2011. Biological treatment of cyanide containing waste water. ResJ Chem Sci 7:15-21.

Ezzi-Mufaddal I, Lynch JM. 2005. Biodegradation of cyanide by Tridodama spp. and Fusanium spp. Enzyme Microb Tech 36: 849-54.

Fallon RD, Cooper DA, Speece R, Henson M. 1991. Anaerobic biodegradation of cyanide under methagenic conditions. Appl Environ Microbiol 57:1656-62.

Fassnacht D, Portner R. 1999. Experimental and theoretical considerations as oxygen supply for animal cell growth in fixed-bed reactors. J Biotechnol 72: 169-84.

Fatma G, Hasan C, A ta A. 2000. Biodegradation of cyanide containing effluents by Scenedesms ddiquus J Hazard Mater 162: 74-9.

Figueira MM, Ciminelli VST, Andrade de MC, Linardi VR. 1996. Cyanide degradation by an Esheriaa adi strain. Can J Microbiol 42: 519-23.

Fry WE, Mills RL. 1972. Cyanide Degradation by an Enzyme from Stemphyum ldi. Arch Biochem Biophys 161: 468- 74.

Gadd G M. 2001. Fungi in bioremediation. Brit Mycol Soc 23: 214- 407.

Guilloton M, Espie GS, Anderson PM. 2002. What is the role of cyanase in plants? Rev Plant Biochem Biotechnol.p. 57-79.

Gurbuz F, Ciftci H, Akcri A. 2009. Biodegradation of cyanide containing effluents by Scenedesmusddiquus J Hazard Mater 179: 72-8.

Huertas MJ, Saez LP, Roldan MD, Loque-Almagro VM, Martinez LM, Moreno VC, Garcia GI. 2010. Alkaline cyanide degradation by Psadommas psandalkalicenes CECT5344 in a batch reactor, Influence of pH.J Hazard Mater 179: 72-8.

Huub JG, Elisabeth B, Henry F. 1999. Cyanide toxicity and cyanide degradation in anaerobic waste water treatment. Water Res 34: 2447-54.

Kaewkannetra P, Imai T, Garcia GFJ, Chiu TY. 2009. Cyanide removal from cassava mill wastewater using Azoddbadervindandii TISTR 1094 with mixed microorganisms in activated sludge treatment system.J Hazard Mater 172: 224-8.
Kao CM, Liu JK, Lou HR, Lin CS, Chen SC. 2003. Biotransformation of cynide to methane and ammonia by Klebsidla oxytoca Chemosphere 50: 1055-61.

Kao CM, Chen KF, Liu JK, Chou SC. 2006. Enzymatic degradation of nitriles by Klebsidla oxytoca Appl Microbiol Biotechnol 71:228-33.

Karamba KI, Shukor MY, Syed MA, Zulkhamain A, Yasid NA, Khali KA, Ahmad SA. 2015. Isolation, screening and characterisation of cyanidedegrading Serratia marcescens strain aq07. J Chem Pharm Sci 8:401-6.

Kowalski M, Bodzek M, Bohdziewicz J. 1998. Biodegradation of phenols and cyanides using membranes with immobilised organisms. Proc Biochem 33:189-97.

Kunz DA, Chen JL, Pan G. 1998. Accumulation of $\alpha$ - keto acids as essential components in cyanide assimilation by Psadommas flucresense NCIMB 11764. Appl Environ Microbiol 64:4452-9.

Kwon HK, Woo SH, Park JM. 2002. Thiocyanate degradation by Acremmiumstricumand inhibition by secondary toxicants. Biotechnol Lett 24: $1347-51$

Lee C, Kim J, Chang J, Hwang S. 2003. Isolation and identification of thiocyanate utilizing chemolitothrophs from gold mine soils. Biodegradation 14: 183-8.

Luque-Almagro VM, Blasco R, Huertas MJ, MartinezLuqueM, Moreno-ViviaC, Castillo F, Rolda MD. 2005. Alkaline cyanide biodegradation by Psadommas psadbalcaligenes CECT5344. Biochem Soc Trans 33:168-9.

Maegala NM, Fridelina S, Abdullatif I, Anthony EG. 2012. Cyanide degradation by immobilised cells of RhodbocausUKMP-5M. Biologia 67(5): 837-44.

Maegala NM, Fridelina S, Abdullatif I. 2011. Biodegradation of cyanide by Rhodbocous strains isolated in Malaysia. International Conference for Food Engineering and Biotechnology 9: 21-5.

Mark JL, Karen H, Terry IM. 1999. The Management of cyanide in gold extraction. International Council on Metals and the Environment. p. 1-3.

Meuwly F, LoviatF, Ruffieux PA, Bernard AR, Kadouri A, von Stockar U. 2005. Oxygen supply for CHO cells immobilized on packed bed of fibra-cel disks. Biotechnol Bioeng 93: 791-800.

Nolan LM, Harnedy PA, Turner P, Hearne AB, Reilly CO. 2003. The cyanide hydratase enzyme of Fusanum lateritium has nitrilase activity. FEMS Microbiol Lett221:161- 5.

Ozel Y K, Gedikli S, Aytar P, Unal A, Yamac M, Cabuk A, KolankayaN.2010. New fungal biomasses for cyanide biodegradation. J Biosci Bioeng 110(4): 431-5.

Paixao MA, Tavares CRG, Bergamasco R, Bonifacio ALE, Costa RT. 2000. Anaerobic digestion from residue 
of industrial cassava industrialisation with acidogenic and methanogenic physical separation phases. Appl Bio chem Biotechnol 84-86: 809-19.

Patil Y B, Paknikar K M. 2000. D evelopment of a process for biodetoxification of metal cyanides from waste waters. Proc Biochem 35: 1139-51.

Plessis du CA, Barnard P, Muhlbauer RM, Naldrett K. 2001. Empirical model for the autotrophic biodegradation of thiocyanate in an activated sludge reactor. LettAppl Microbiol 32: 103-7.

Potivichayanon S, Kitleartpornpairoat R. 2010. Biodegradation of cyanidebynovel $\mathrm{c}$ y a $\mathrm{n}$ i d e degrading bacterium. World Acad Sci Eng Technol 42: 1362-5.

Quesada A, Guijo MI, Merchan F, Blazquez B, Igeno MI, Blasco R. 2007. Essential role of cytochrome bdrelated oxidase in cyanide resistance of Psaddmonas psaudoalcaligens CECT5344. Appl Environ Microbiol73:5118- 24.

Raybuck SA. 1992. Microbes and microbial enzymes for cyanide degradation. Biodegradation 3:3-18.

Reilly CO, Turner PD. 2003. The nitrilase family of CN hydrolysing enzymes - a comparative study. J Appl Microbiol95: 1161-74.

Rezende RP, Dias JCT, Ferraz V, Linardi VR. 2000. Metabolism of benzonitrile $\mathrm{b} \quad \mathrm{y}$ Cryptococaussp. UFMG-Y28. J Basic Microbiol 40: 389-92.

Shivaraman N, Parhad NM. 1985. Biodegradation of cyanide by Psaddommas acidovarans and influence of $\mathrm{pH}$ and phenol. Indian J Environ Health 27:1-8.
Sirianuntapiboon S, Chuamkaew C. 2007. Packed cage rotating biological contactor system for treatment of cyanide waste water. Bioresource Technol 98: 266-72.

Skowronski B, Strobel GA. 1969. Cyanide resistance and cyanide utilisation by a strain of Baillus pumilus Can J Microbiol 15: 93-8.

Sorokin DY, Tourova TP, Lysenko AM, Kuenen JG. 2001. Microbial thiocyanate utilisation under highly alkaline conditions. Appl Biochem Microbiol 67: 528-38.

Stephen E. 2004. Biological degradation of cyanide compounds. Curr O pin Biotechnol 15:231-6.

Suh Y, Park JM, Yang J. 1994. Biodegradation of cyanide compounds by Psandommas fluoresensimmo bilised on zeolite. Enzyme Microb Tech 16:529-33.

White D M, Schnabel W. 1998. Treatment of cyanide waste in a sequencing batch biofilm reactor. Water Res 32: $254-7$.

Yamasaki M, Matsushita Y, Namura M, Nyunoya $H$, Katayama Y. 2002. G enetic and immunochemical characterization of thiocyanate-degrading bacteria in lake water, Appl Biochem Microbiol 68: 942-6.

Young CA, Jordan TS. 1995. Cyanide remediation: current and past technologies, in Proceedings of the $10^{\text {th }}$ Annual Conference on Hazardous Waste Resources. p. 104- 29.

Zhou X, Liu L, Chen Y, Xu S, Chen J. 2007. Efficient biodegradation of cyanide and ferrocyanide by $\mathrm{Na}$-alginate beads immobilised with fungal cells of Tridodamakonini. Can J Microbiol 53: 1033- 7. 